\title{
PEMERIKSAAN KESEHATAN DAN PENYULUHAN KESEHATAN \\ DI DUSUN KRAMPYANG, DESA KALIPANG, KECAMATAN GROGOL, KABUPATEN KEDIRI \\ (KERJA SAMA DENGAN) \\ LEMBAGA AMIL ZAKAT “NURUL HAYAT” DAN "BSMI KABUPATEN KEDIRl”
}

\author{
Bambang Wiseno* \\ *Dosen Stikes Pamenang Pare - Kediri \\ * Ketua Relawan Tanggap Bencana Perhimpunan Bulan Sabit Merah Indonesia (BSMI) Kabupaten Kediri \\ Email: bambangwiseno72@yahoo.com, bambangwiseno0601@gmail.com
}

\begin{abstract}
$\underline{\text { ABSTRAK }}$
Kekeringan menyebabkan berbagai masalah dalam kehidupan manusia. Orang-orang di dusun Krampyang, desa Kalipang, Kecamatan Grogol telah mengalami banyak masalah kesehatan di daerah tersebut. Letak geografis di lereng gunung wilis yang jauh dari layanan kesehatan, menyebabkan masyarakat kurang memiliki perilaku kesehatan. Misalnya, orang-orang menggunakan obat-obatan bebas untuk mengatasi masalah kesehatan mereka. Berdasarkan masalah-masalah itu, melalui Lembaga Amil Zakat "Nurul Hayat" sebagai penyandang dana bekerja sama dengan Perhimpunan Bulan Sabit Merah Indonesia Kabupaten Kediri dan Stikes Pamenang dengan Tim Kesehatannya, mereka tergerak untuk mengurangi beban pada warga dalam mengatasi masalah kesehatan. Layanan sosial diberikan oleh Tim Kesehatan pada 28 September 2019 dengan asumsi layanan kesehatan dan pendidikan kesehatan kepada penduduk. Sebanyak 8,5\% dari sekitar 1.200 penduduk memanfaatkan kegiatan ini untuk memeriksa kesehatan mereka secara gratis dan mendapatkan obat sesuai indikasi penyakit mereka. Dari hasil pemeriksaan, ditemukan bahwa masyarakat yang mengalami masalah kesehatan tertinggi di daerah ini adalah; tekanan darah tinggi sebanyak $38,2 \%$ dan gangguan sendi / otot sebanyak $29,4 \%$. Berdasarkan kondisi ini, konseling tentang efek negatif dari penggunaan obat bebas, masalah hipertensi dan masalah osteoporosis diberikan untuk meningkatkan pengetahuan warga tentang kesehatan sehingga konsekuensi dari masalah ini dapat dikurangi.
\end{abstract}

Kata Kunci: Kemarau, Kesehatan Masyarakat, Bakti Sosial.

\section{$\underline{A B S T R A C T}$}

Drought cause various problems in human lives. The people's in dusun Krampyang, desa Kalipang, Kecamatan Grogol have been experienced that's many health problems in the area. The geographical location's on the slope of the wilis mountain which is far from the health services, causing the peoples have lack of health behavior. For example, the people are use of over-the-counter medicines to treath their health problem. Based on these problems, through the Amil Zakat Institution "Nurul Hayat" as a funder in collaboration with the Indonesian Red Crescent Association and Stikes Pamenang with their Health Team, they are action to reduce the burden on citizens in overcoming health problem. Social services were given by the Health Team on September 28, 2019; that's are health services assement and health education to residents. As many as $8.5 \%$ of around 1200 residents take advantage of this activity to check their health for free and get medicine according to the indication of their illness. From the examination results, it was found that the public experienced the highest health problems in this area are; high blood pressure as much as $38.2 \%$ and joint / muscle disorders as much as $29.4 \%$. Base on these conditions, counseling about the negative effect using of over-the-counter drugs, hypertension problems and osteoporosis problems is given to increase citizens' knowledge about health so that the consequences of these problems can be reduced.

Keywords: Drought, Public Health, Social Service. 


\section{A. Analisis Situasi}

Kesehatan merupakan salah satu unsur yang berpengaruh pada perkembangan hidup manusia, untuk itu diperlakukan usaha-usaha yang dapat meningkatkan taraf kesehatan masyarakat Indonesia. Dewasa ini, baik pemerintah maupun lembaga non pemerintah sedemikian gencarnya menjalankan program-program kesehatan demi tercapainya tujuan tersebut. Adapun sasaran dari program-program ini adalah masyarakat luas pada umumnya.

Dusun Krampyang, Desa Kalipang, Kecamatan Grogol, Kabupaten Kediri yang menjadi lokasi kegiatan bakti sosial pada kali ini merupakan daerah pedesaan yang terdampak kekeringan musim kemarau tahun 2019 ini. Perekonomian akibat kekeringan tentunya memberikan dampak terhadap ketahanan pangan hingga derajat kesehatan masyarakat yang perlu untuk diperhatikan. Ditambah dengan jarak akses terhadap fasilitas pelayanan yang terhitung jauh menuju Puskesmas Grogol menjadi faktor pentingnya untuk dilakukan bakti sosial berupa deteksi dini kondisi sehat sakit, pemeriksaan kesehatan, pemberian obat dasar dan penyuluhan terhadap perilaku preventif agar tingkat kesehatan masyarakat terjaga.

STIKES Pamenang yang merupakan lembaga pendidikan kesehatan siap bekerja sama dengan lembaga kesehatan dan kemanusiaan lain tentunya tidak ingin hanya berpangku tangan dalam menyikapi hal ini. Sehubungan dengan Tridharma Perguruan Tinggi khhusunya pengabdian pada masyarakat, memiliki tanggung jawab untuk melibatkan diri secara aktif sesuai dengan kemampuan untuk berupaya meningkatkan kesejahteraan sosial masyarakat di Dsn. Krampyang Ds. Kalipang Kec. Grogol..

\section{B. Perumusan Masalah}

Berdasarkan analisa situasi diatas, kami berdiskusi dengan Tim Nurul Hayat dan Bulan Sabit Merah Indonesia Kabupaten Kediri Seksi Pelayanan kesehatan (kegiatan bakti sosial), maka dengan permasalahan yang ada tersebut, disepakati melakukan pelayanan kesehatan berupa pemeriksaan kesehatan dan penyuluhan kesehatan kepada masyarakat Dsn. Krampyang Ds. Kalipang Kec. Grogol sebagai bentuk pengabdian masyarakat dalam Tridharma Perguruan Tinggi bagi penulis sebagai dosen pengajar.

\section{Realisasi Penyelesaian Masalah}

Menumbuhkan sikap berbakti dan mengabdi para pada masyarakat, khususnya melalui bidang kesehatan, memberikan informasi dan pengetahuan kesehatan kepada masyarakat. Memberikan pelayanan kesehatan secara langsung kepada masyarakat. Memberikan pemikiran berdasarkan ilmu pengetahuan dan teknologi dalam upaya untuk menumbuhkan dan mempercepat gerak pembangunan khususnya di bidang kesehatan.
Melalui kegiatan pengabdian masyarakat, kami sebagai dosen di STIKES Pamenang berusaha mewujudkan peran serta dalam pembangunan nasional dan sebagai bukti kepekaan terhadap problematika masyarakat serta sebagai tolak ukur untuk menilai kemampuan pelayanan kesehatan. Bekerja sama dengan Lembaga Amil Zakat Nurul Hayat Kabupaten Kediri dan Bulan Sabit Merah Indonesia Cabang Kabupaten Kediri sebagai lembaga kemanusiaan yang berizzah pada kesehatan dan bergerak dalam bidang sosial merupakan bagian integral dari masyarakat dan bangsa Indonesia yang tak terpisahkan, tentunya tidak ingin hanya berpangku tangan dalam menyikapi hal ini. Kami memiliki tanggung jawab untuk melibatkan diri secara aktif sesuai dengan kemampuan yang kami miliki untuk berupaya meningkatkan kesejahteraan sosial masyarakat di Dsn. Krampyang Ds. Kalipang Kec. Grogol. Kab. Kediri.

\section{Khalayak Sasaran}

Khalayak sasaran pada kegiatan pelayanan kesehatan ini yaitu warga masyarakat yang mengalami masalah kesehatan di Dsn. Krampyang, Ds. Kaslipang, Kec. Grogol, Kab. Kediri.

\section{E. Persiapan}

Persiapan yang dilakukan dalam kegiatan pengabdian masyarakat ini adalah berkoordinasi dengan Lembaga Amil "Nurul Hayat" Kab.Kediri dan Perhimpunan Bulan Sabit Merah Indonesia (BSMI) Cabang Kab. Kediri meliputi:

1. Perijinan dan koordinasi dengan BSMI Cabang. Kab. Kediri untuk memberikan pelayanan kesehatan;

2. Persiapan alat dan kebutuhan obat-obatan dasar untuk layanan kesehatan;

3. Pengurusan kelengkapan administrasi kegiatan pengabdian masyarakat termasuk surat tugas dari Ketua Stikes Pamenang Pare-Kediri dan surat tugas permintaan bantuan tenaga sebagai tim kesehatan dari BSMI Cabang Kab. Kediri;

4. Menyiapkan proposal kegiatan pengabdian masyarakat yang berisi Preplanning kegiatan koordinasi dengan Lembaga Amil "Nurul Hayat" Kab Kediri sebagai penyandang dana dan BSMI Cabang Kab. Kediri sebagai pelaksana kegiatan.

\section{F. Metode yang Digunakan}

Kegiatan yang dilakukan dengan memberikan pelayanan kesehatan yang berupa pemeriksaan kesehatan dan pengkajian kesehatan khususnya masalah kejiwaan untuk bisa melakukan dukungan kesehatan jiwa / psikososial serta pembagian bantuan bahan pokok. Bersama dengan tim medis dari BSMI memberikan obat-obatan standar dasar bagi yang terdeteksi mengalami penyakit.

\section{G. Kegiatan}

Pelaksanaan layanan kesehatan, dilakukan pada tanggal 28 September 2019 di dusun Krampyang, desa Kalipang, kecamatan Grogol: 
1. Layanan Kesehatan berupa pemeriksaan kesehatan dan pengobatan dasar diberikan pada 98 warga di posko layanan baksos dan 4 warga dengan home visite ke rumah warga.

2. Penyuluhan Kesehatan (Health Education) kepada warga masyarakat tentang resiko mengkonsumsi obat-obat bebas.

3. Pembagian paket sembako dari Lembaga Amil "Nurul Hayat" sebanyak 20 paket kepada keluarga yang kurang mampu.

\section{H. Evaluasi Hasil :}

1. Warga yang memeriksakan kesehatan dan mendapatkan pengobatan standar sebanyak 102 orang selama kegiatan dilakukan dari total jumlah penduduk Dusun Krampyang Desa Kalipang sekitar 1200 jiwa.

2. Dari hasil tabulasi pelayanan pemeriksaan kesehatan didapatkan penggolongan sebagai berikut

a. Berdasarkan umur:

- Balita: 4 = 3.9\%

- $\quad$ Anak-anak dan Dewasa: $27=26.5 \%$

- Lansia: $71=69.6 \%$

b. Berdasarkan jenis kelamin:

- Laki-laki: $41=40.2 \%$

- Perempuan: $61=59.8 \%$

c. Berdasarkan keluhan yang ditemukan:

- Gangguan Pencernakan: $17=16.6 \%$

- Gangguan Pernafasan: $7=6.8 \%$

- $\quad$ Tekanan darah tinggi: $39=38.2 \%$

- $\quad$ Penyakit kulit: $4=3.9 \%$

- Gangguan persendian/otot: $30=29.4 \%$

- Lain-lain: $5=4.9 \%$

3. Sebanyak 20 paket bahan pokok dibagikan kepada keluarga kurang mampu.

\section{Pembahasan}

Hidup di lereng pegunungan di musim kemarau mengakibatkan rendahnya pendapatan ekonomi masyarakat karena berkurangnya hasil pertanian dan peternakan yang menjadi mata pencaharian warga. Dsn. Krampyang ds. Kalipang kec. Grogol terdiri dari 1 Rukun Warga dengan 4 Rukun Tetangga, berjumlah penduduk sekitar 1200 orang sangat membutuhkan layanan kesehatan. World Bank (2002), menyatakan bahwa kemiskinan dan kesehatan merupakan sesuatu yang tidak dapat dipisahkan. Kesehatan yang buruk dapat menyebabkan kemiskinan dan kemiskinan berpotensi besar membawa pada status kesehatan yang rendah. Kesehatan merupakan tingkat fungsional seseorang baik fisiologis, psikologis dan sosialkultural. Pendidikan dan kesehatan merupakan investasi untuk mendukung pembangunan ekonomi dan berperan dalam upaya penanggulangan kemiskinan. Kemiskinan merupakan permasalahan yang mencakup berbagai bidang dan bersifat lintas sektoral yang menjadi tanggung jawab semua warga negara. Nurul Hayat, BSMI sebagai Lembaga sosial masyarakat dan penulis sebagai salah satu pengajar di institusi pendidikan kesehatan tergerak melakukan pemeriksaan kesehatan untuk meringkankan beban ekonomi masyarakat tersebut.

Lingkungan merupakan salah satu faktor yang menyebabkan terjadinya penyakit, selain host dan agent. Lingkungan yang tidak memungkinkan warganya mendapatkan layanan kesehatan yang baik, akan mencari jalan lain yang dirasa bisa membantunya. Pemakaian obat-obatan bebas oleh orang-orang yang tidak memahami efek samping dalam pemakaiannya akan mempengaruhi kesehatan selanjutnya pada orang tersebut. Dari hasil wawancara dengan beberapa orang warga di Dsn. Krampyang Ds. Kalipang Kec. Grogol didapatkan bahwa, karena jauhnya layanan kesehatan maka bila sakit sejak dulu warga sudah biasa mengkonsumsi obat-obat yang dijual bebas di warung tanpa pengawasan. Pada kegiatan kali ini penyuluhan kesehatan (health education) diberikan kepada warga terkait masalah penggunaan obat bebas, khususnya pada lansia yang sebagian besar memeriksakan diri pada kesempatan ini.

Stress tinggi karena faktor ekonomi menyebabkan meningkatnya tekanan darah, sehingga wajar terjadi pada warga di lokasi baksos. Nyeri persendian sebagai salah satu tanda Osteoporis banyak dialami oleh warga, hal ini dimungkinkan karena akifitas sehari-hari warga sebagi petani dan peternak yang harus naik turun gunung untuk mencari pakan ternak dan bertani. Penyuluhan tentang hipertensi dan osteoporosis diberikan secara individu kepada warga yang mengalaminya untuk bisa mencegah terjadinya kekambuhan.

\section{J. Kesimpulan}

Kemarau panjang memungkinkan warga mengalami kesulitan dalam perekonomian yang berimbas pada kebutuhan kesehatan. Dusun Krampyang Ds. Kalipang Kec. Grogol berada di kaki lereng gunung Wilis yang jauh dari tempat layanan kesehatan menyebabkan warga menggunakan obat-obat yang dijual bebas di warung tanpa pengawasan untuk mengatasi permasalah sakitnya. Sebanyak 8,5\% dari total sekitar 1200 warga mendapatkan layanan kesehatan gratis dari tim kesehatan BSMI dan Nurul Hayat serta 20 kepala keluarga menapatkan bantuan paket sembako. Tokoh masyarakat setempat mewakili warga, sangat mengharapkan adanya layanan kesehatan yang dekat dan mudah dapat diterima oleh warganya. Penyuluhan kesehatan diberikan kepada warga sesuai keluhan yang dirasakannya.

\section{K. Saran}

1. Bagi Pemerintah

Pemerataan tenaga kesehatan hendaknya dilakukan untuk menghindari permasalah kesehatan yang lebih banyak di masyakat. Daerah yang jauh dari layanan kesehatan cenderung warganya menggunakan obat-obatan yang dijual bebas di warung-warung untuk mengatasi masalah sakitnya yang dapat 
menimbulkan masalah kesehatan yang lebih pada warga penggunanya.

2. Bagi Lembaga Sosial Masyarakat

Kerja sama antar lembaga sosial masyarakt dengan lembaga lain bidang kesehatan harus saling dan mampu berkoordinasi dengan pemerintah dalam menghadapi dan menyelesaikan permasalah kesehatan yang ada di masyarakat.

3. Bagi Intitusi Pendidikan Kesehatan

Keterlibatan tenaga dosen dari intitusi pendidikan kesehatan dalam masalah kesehatan di masyarakat dapat meningkatkan kepekaan civitas akademika dalam kewajibannya di Tridharma Perguruan Tinggi, khususnya pada pengabdian kepada masyarakat.

Mengikutsertakan dosen dalam pelayanan kesehatan di msayarakat dapat menambah ilmu dan pengetahuan yang nyata dan dapat dibagikan kepada anak didik.
BSMI (2007). Anggaran Dasar \& Anggaran Rumah Tangga Perhimpunan Bulan Sabit Merah Indonesia. Web:http://bsmi.oc.id

Statistik, B. P. (2009). Profil Kemiskinan di Indonesia Maret 2009. Berita Resmi Statistik, (45/07).

Suryawati, C. (2005). Memahami kemiskinan secara multidimensional. Jurnal Manajemen Pelayanan Kesehatan,8(03).

Undang-undang RI No 36 Tahun 2009 tentang Kesehatan.

World Bank, 2002, Dying for Changhe: Poor People's Experience of Health and III.

World Health Organization. Definisi Sehat WHO: WHO; 1947 [cited 201620 February]. Available from: www.who.int.

Zuhdiyaty, N., \& Kaluge, D. (2017). Analisis FaktorFaktor Yang Mempengaruhi Kemiskinan Di Indonesia Selama Lima Tahun Terakhir. Jurnal IImiah Bisnis dan Ekonomi Asia, 11(2), 27-31.

\section{REFERENSI:}

